\title{
Results of Testing at Site 41KA87 Karnes County, Texas
}

\author{
Alan J. Wormser
}

A. Joachim McGraw

Follow this and additional works at: https://scholarworks.sfasu.edu/ita

Part of the American Material Culture Commons, Archaeological Anthropology Commons, Environmental Studies Commons, Other American Studies Commons, Other Arts and Humanities Commons, Other History of Art, Architecture, and Archaeology Commons, and the United States History Commons

Tell us how this article helped you.

This Article is brought to you for free and open access by the Center for Regional Heritage Research at SFA ScholarWorks. It has been accepted for inclusion in Index of Texas Archaeology: Open Access Gray Literature from the Lone Star State by an authorized editor of SFA ScholarWorks. For more information, please contact cdsscholarworks@sfasu.edu. 


\section{Results of Testing at Site 41KA87 Karnes County, Texas}

\section{Licensing Statement}

This is a work produced for the Texas Department of Transportation (TxDOT) by the report producer. TxDOT and the report producer jointly own all rights, title, and interest in and to all intellectual property developed under TXDOT's contract with the report producer. The report may be cited and brief passages from this publication may be reproduced without permission provided that credit is given to both TxDOT and the report producer. Permission to reprint an entire chapter, section, figures or tables must be obtained in advance from either the Supervisor of the Archeological Studies Branch, Environmental Affairs Division, Texas Department of Transportation, 125 East 11th Street, Austin, Texas, 78701 or from the report producer. 


\title{
RESULTS OF TESTING AT SITE 41KA87 KARNES COUNTY, TEXAS
}

\section{by}

\author{
Alan J. Wormser \\ and
}

A. Joachim McGraw

Texas

State Department of Highways and Public Transportation

Highway Design Division

November 1988 


\begin{abstract}
Archaeological site 41KA87 was tested by the cultural resources staff of the State Department of Highways and Public Transportation (SDHPT) in September, 1987. Few prehistoric tools were found and well-defined features were lacking. Cultural deposits were about $50 \mathrm{~cm}$ thick and contained lithic debris, mussel shell, and other evidence of prehistoric occupation. The cultural material recovered suggests that site 41KA87 was occupied during the Late Archaic and Late Prehistoric periods. The site is not considered eligible for inclusion in the National Register of Historic Places, and it is not recommended for listing as a State Archeological Landmark.
\end{abstract}




\begin{abstract}
. . . . . . . . . . . . . . . . . . . . . . . . . 2

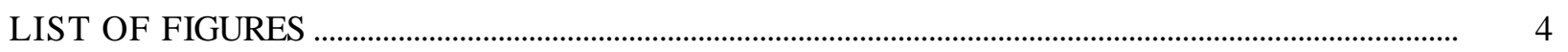

LIST OF TABLES . . . . . . . . . . . . . . . . . . . . . . . . . . . 5

INTRODUCTION . . . . . . . . . . . . . . . . . . . . . . . . . . . . 6

ENVIRONMENTAL BACKGROUND . . . . . . . . . . . . . . . . . . . . . . . . 8

CULTURAL BACKGROUND . . . . . . . . . . . . . . . . . . . . . . . . . . . 9

Previous Archaeological Research . . . . . . . . . . . . . . 9

Chronological Sequence . . . . . . . . . . . . . . . . . 11

SITE DESCRIPTION . . . . . . . . . . . . . . . . . . . . . . 12

TEST EXCAVATIONS .......................... . 14

Testing procedures ................... . . . 14

Stratigraphy .......................... 16

Artifact Descriptions. . . . . . . . . . . . . . . . . 18

CONCLUSIONS . . . . . . . . . . . . . . . . . . . . . . . . 26

REFERENCES CITED . . . . . . . . . . . . . . . . . . . . . . . 27
\end{abstract}




\section{LIST OF FIGURES}

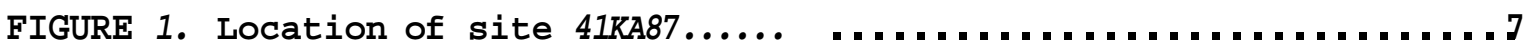

FIGURE 2. Location of test units, profiles, and trenches at site

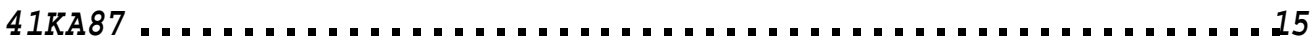

FIGURE 3. Soil Profiles from Trench A.......................17

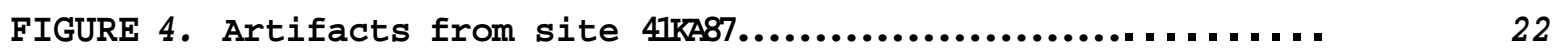

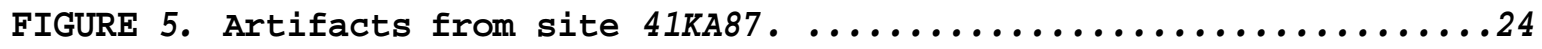




\section{LIST OF TABLES}

TABLE 1. Artifact summary. . . . . . . . . . . . . . . . . . . . . . 19

TABLE 2. Distribution of flakes by decortication type. . . . . . . . . 20 


\section{INTRODUCTION}

The planned construction of a bridge by the Texas State Department of Highways and Public Transportation (SDHPT) on State Highway 72 six miles east of Kenedy, Texas, at the San Antonio River will impact archaeological site 41KA87 (Figure 1). The project will replace two existing bridges, the earliest of which was built in 1928. A relief bridge, built in 1940, is adjacent to the earlier structure. Both bridges are scheduled to be replaced by a single concrete bridge. The SDHPT has completed its coordination with the Texas Historical Commission (THC) regarding the old bridges .

Site 41KA87 was discovered during a routine survey of the project by the SDHPT cultural resources staff. Archaeological testing was conducted in early September 1987. In a meeting on September 18, 1987, the testing results were presented to the THC by members of the SDHPT cultural resources staff. In a follow-up letter dated September 18, 1987, Ms. Nancy A. Kenmotsu of the THC concurred that no further archaeological investigation was required for site 41KA87. Ms. Kenmotsu's letter also stipulated that a written report of the test results and geomorphic interpretations of the site should "be forthcoming in the near future." This report is intended to satisfy both requirements. 
This Page Redacted Per THC Policy 


\section{ENVIRONMENTAL BACKGROUND}

Karnes County is part of the Gulf Coastal Plain which extends from the Balcones Escarpment southeastward to the Gulf of Mexico. The average annual precipitation in the County is 32 inches (Carr 1977:4; Larkin and Bomar 1983:18). The site occurs within a climatic zone which Carr: (1977:6, 11-14) identified as the South-Central Division of the Interior Region of Texas. The Interior Region includes most of Texas. Maximum precipitation amounts in this region occur in late spring and early autumn. Winters tend to be dry and mild; summers are dry and hot. In general, the region is subtropical-subhumid to subtropical-humid.

Karnes County is located near the boundary between the Tamaulipan and Texan Biotic Provinces (Blair 1950). The Texan Biotic Province is a broad ecotonal zone between the Austroriparian forests of east Texas and the drier grasslands and brush country of the Tamaulipan Biotic Province, which extends into northeastern Mexico. 


\section{CULTURALBACKGROUND}

\section{PREVIOUS ARCHABOLOGICAL RESEARCH}

In Karnes County, most of the previous archaeological research has been limited to surveys for power lines and uranium prospects. Examples include surveys reported by Andrews (1981), and Nightengale and Bement (1982). Other projects in Karnes County include the Conquista O il leases (McGraw 1979, Roemer 1980), and flood control projects along Ecleto Creek (Cole 1981, Crawford 1971, Kotter and Guy 1980).

Several sites in Karnes County have been excavated. These include 41KA1 (Calhoun 1979); and 41KA25, 41KA26, and 41KA85 (Denton 1984, Goode n.d.). A t 41KA1, Calhoun reported finding 2 plain globular ollas with narrow necks and bone temper. The site dates to the Late Prehistoric and may be related to the mission Indians in the surrounding area. Sites 41KA25, 41KA26, and 41KA85 occur in a cluster on Cibolo Creek. Site 41KA26 is a Spanish Colonial site, roughly contemporaneous with other colonial sites in the region. Sites 41KA25 and 41KA85 have mainly prehistoric components. However, Goode (n.d.) suggests lithic tools remained important for the Indians well into the Spanish Colonial period.

More archaeological investigations have been carried out in some of the counties surrounding Karnes County. In Wilson County, the Rancho de 1 as Cabras site was excavated over several field seasons (Ivey 1983, Ivey and Fox 1981, Jones and Fox 1983, Taylor and Fox 1985). Research has also been 
conducted in the Cibolo Reservoir (Hsu and Ralph 1968) and in public parks (Cox 1978, Laurens et al 1979).

The most intensive series of investigations involved the Choke Canyon Reservoir in Live Oak County (Bandy 1981; Brown et al 1982; Campbell and Campbell 1981; Everett 1981; Fox 1984, 1986; Hall et al 1982; Hall et al 1986; Highley 1986; Jurgens 1980; Labadie 1985; Lynn 1977; Roemer 1981; Scott and Fox 1982; Thoms et al 1981; Wakefield 1968; Weed and Shafer 1981). The Three Rivers region has also been studied by archaeologists (Dibble 1979; Mallouf 1975, 1977; Pliska 1980; Prewitt 1977). The SDHPT has conducted research near Oakville (Patterson 1987) and at the Loma Sandia Site, 4lLK28 (Johnson 1977).

Goliad County has also been well studied by archaeologists and historians. Mission Espiritu Santo has been described by Mounger (1959). The burials which were found (Reed 1983) have given us insight into the lifestyles at the early Spanish missions. More recently, research has been conducted at Coleto Creek (Fox and Hester 1979, Fox et al 1979, Fox 1979, McReynolds 1987) and Mission Rosario (Gilmore 1974, 1975). Investigations at the historic townsite of Riverdale were carried out by the SDHPT (Clark 1985).

In Atascosa, Bee, Gonzales and De Witt Counties, most of the archaeology has been limited to surveys for transmission lines and pipelines. Paleoindian artifacts from Atascosa and De Witt Counties have been examined by several authors (Birmingham 1980; Hester 1968; McReynolds et al 1979, 1980). 
The archaeological chronology of the Central Texas and the adjacent regions has been the subject of debate in recent years (Weir 1976, Prewitt 1981). Johnson (1986) has raised some important philosophical questions with the concepts used in forming these chronologies. Rather than attempt to assign controversial "Phase" designations to the components at 41KA87, the site has been placed within a more general framework of time periods while maintaining consistency with previous research in Central and Southern Texas.

For simplicity, the following time periods were used:

$\begin{array}{lr}\begin{array}{l}\text { Paleo-Indian Period } \\ \text { Archaic Period }\end{array} & 20,000-9000 \text { B.P. } \\ \text { Early } & 9000-6000 \text { B.P. } \\ \text { Middle } & 6000-4000 \text { B.P. } \\ \text { Late } & 4000-2000 \text { B.P. } \\ \text { Transitional } & 2000-1200 \text { B.P. } \\ \text { Late Prehistoric Period } & \\ \text { Early } & 1200-600 \text { B.P. } \\ \text { Late } & 600-200 \text { B.P. }\end{array}$




\section{SITE DESCRIPTION}

Site 41KA87 is located 6 miles east of Kenedy, Texas, where SH 72 crosses the San Antonio River. The site is on the upper slope and crest of a prominent hill less than 200 meters southwest of the river. Modern vegetation at the site consisted of thornbush which was partially cleared just before the archaeological survey. The soil is alluvial, and consists of a sandy loam which grades to clayey loam.

No material was collected from the surface during the initial survey, but burned rock, chert flakes, and mussel shell fragments were observed. Based on the distribution of surface debris and the size and shape of the hill, the site limits were estimated to be 75 meters wide(along the northwest to southeast axis) by 150 meters long (along the northeast to southwest axis), for a total site area of about 11,250 square meters.

Small, disturbed clusters of burned rock were visible along the fence line in the northwest portion of the site, but no well-defined features could be identified. Test excavations of the site revealed that the cultural deposits extended from the surface to about $50 \mathrm{~cm}$ in depth.

The site is a prehistoric campsite with mixed Late Archaic and Late Prehistoric components. The only diagnostic artifacts found include a prehistoric pottery sherd, and a dart point fragment with a parallel-sided stem. 
The general lack of implements recovered suggests that the site occupations were ephemeral and that the diversity of on-site activities was low. Identifiable site activities include chert knapping and food preparation.

Mussel shell fragments werecommon in the test units. Small mussels apparently provided a food staple during one or more of the occupations. This, and the use of gravel as a source for lithic material, imply that the prehistoric occupants predominantly exploited riverine resources.

Previous disturbances to the site include the construction of SH 72 and the more recent construction of a new right-of-way fence through the site. In addition, the portion of the site within the original right-of-way has been scraped and graded for many years. Although the site is located on a hill overlooking the San Antonio River, the overall shape of the valley immediately east of the site and the presence of old channel scars indicates that the river has been very active. Currently, the river is cutting toward the site. 


\title{
TEST EXCAVATIONS
}

\author{
TESTING PROCEDURES
}

Within the right-of-way, three 1-by-1 meter test units were dug using shovels and trowels (Figure 2). The units were excavated in arbitrary $10 \mathrm{~cm}$ levels to a sterile stratum consisting of compacted caliche. All soil matrix from the test units was passed through screens of 1/4-in. hardware cloth. Artifacts recovered in the screens were placed in labelled bags. Soil samples were taken from each of the levels of each test unit.

In addition to the test units, three backhoe trenches were excavated. Trench A was parallel to and south of SH 72. A short trench, Trench B, was excavated perpendicular to and near the east end of Trench A. Trench $\mathrm{C}$ was placed on the opposite side of the right-of-way and parallel to Trench A. The trenches were excavated in several passes with a backhoe, removing 5 to $10 \mathrm{~cm}$ of soil at a time. A member of the SDHPT cultural resources staff monitored the backhoe operations in case any features were uncovered. None were observed

Cultural material was present in all of the trenches. There was little cultural material in Trench $\mathrm{C}$, and the deposits were disturbed. Because of this, the three test units were placed near Trenches A and B. A transit was used to map the site, and was also used to maintain vertical control of test units. 


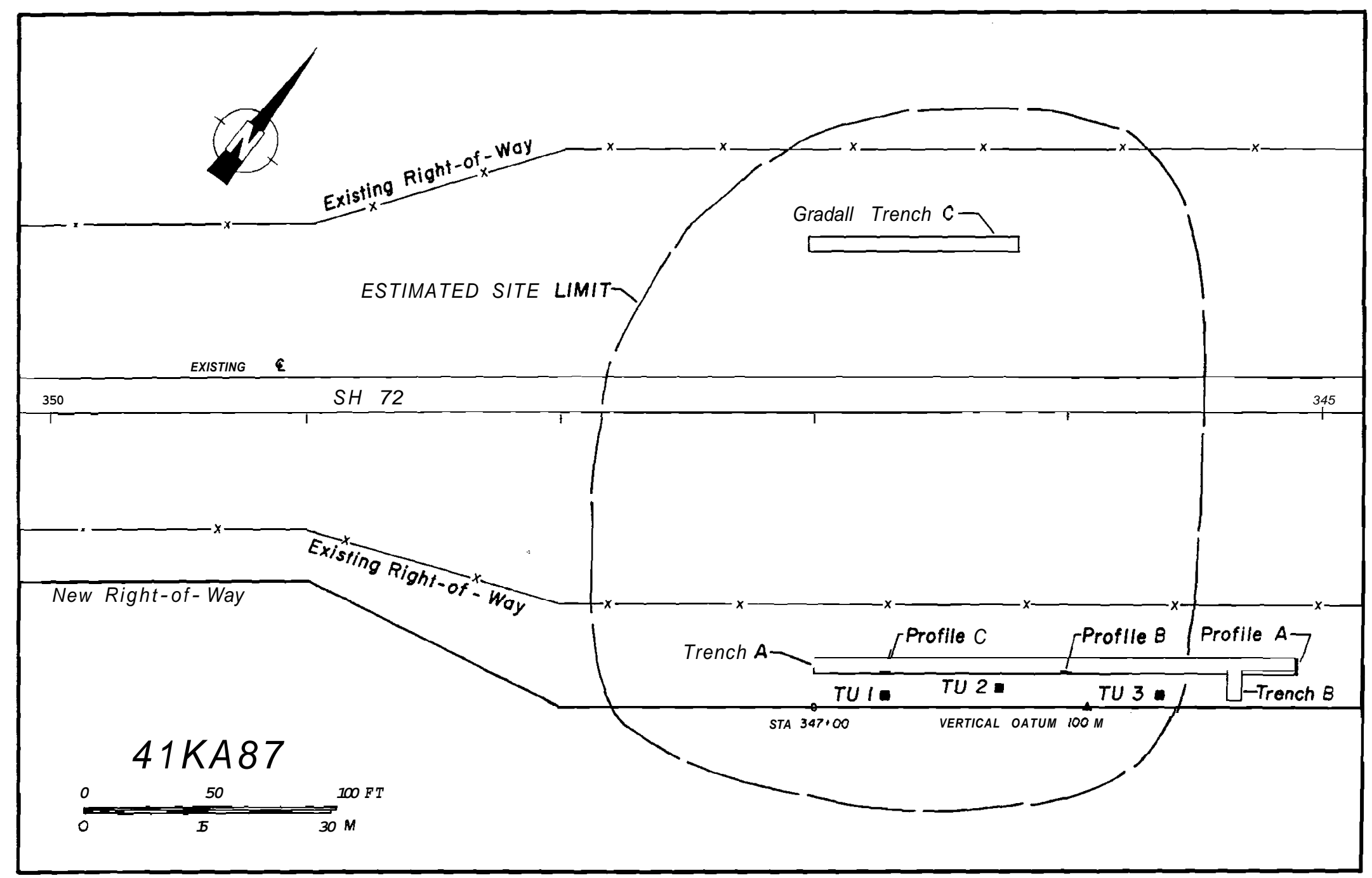

FIGURE 2. Location of test units, profiles, and trenches a t Site $41 K A 87$. 
Three profiles (labelled A, B, and C) were drawn for Trench A and are shown in Figure 3. Profiles B and C are similar, but Profile A, at the north end of the trench, contained more gravel than the other two. This northernmost profile is outside the limits of the site and is colluvial in origin. The upper soil zone is brown loam with small gravel. From 20 to $30 \mathrm{~cm}$ below the surface the soil is of similar texture, but is light brown in color. Below $30 \mathrm{~cm}$, the soil matrix is predominantly caliche nodules and gravel, and compacted caliche was found at a depth of 50 to $60 \mathrm{~cm}$.

In Profiles B and $\mathrm{C}$, the uppermost soil is light to medium brown, sandy loam. Below this soil is a zone of slightly more compacted, medium brown loam with occasional caliche nodules. The third zone is a light brown clay loam with frequent caliche nodules. The bottom of the profiles consists of tan clay loam with a high caliche content. The transition between the soil zones is gradual. 


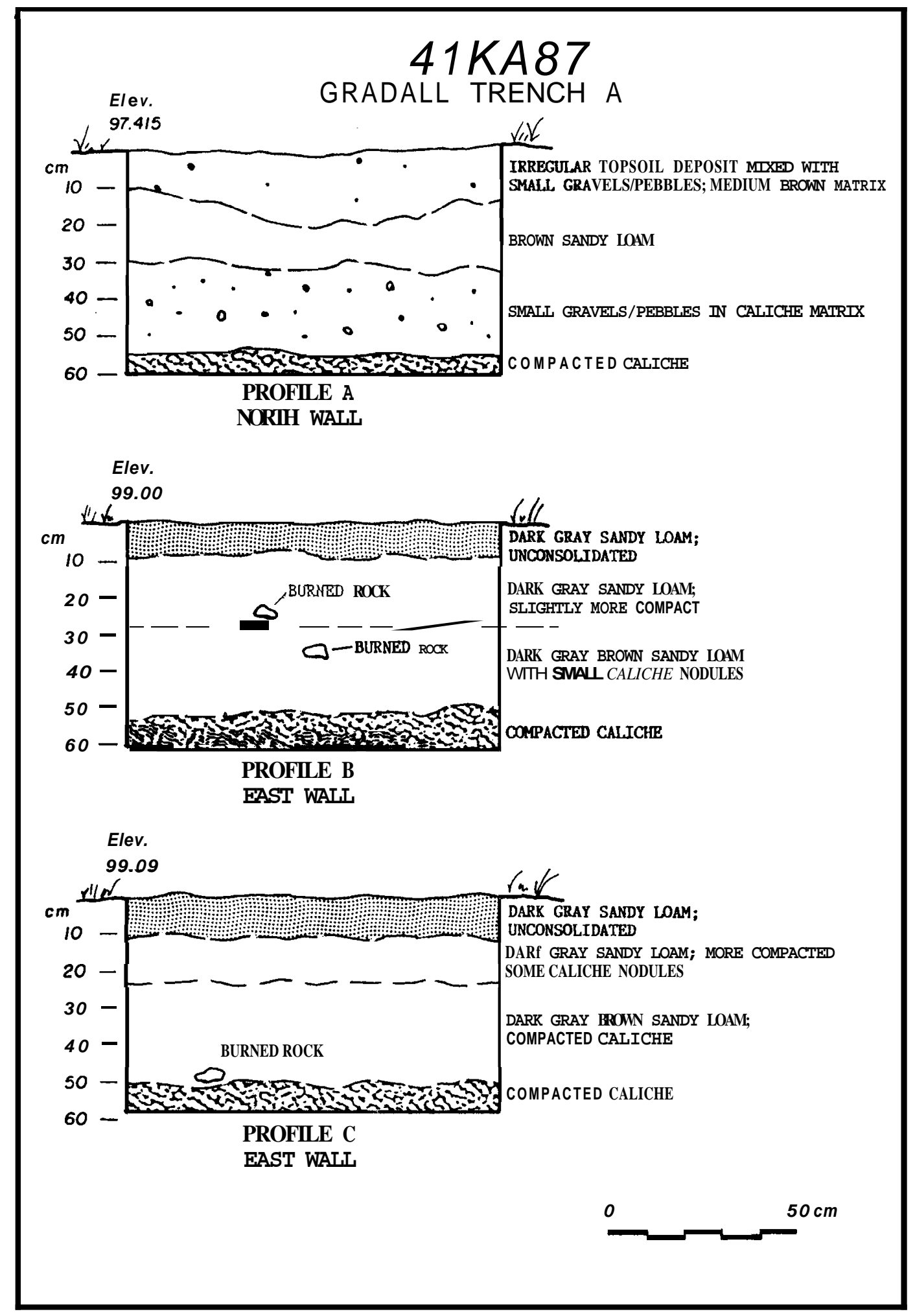

FIGURE 3. Soil profiles from Trench A, Site $41 \mathrm{KA} 87$. 


\section{ARTIFACT DESCRIPTIONS}

The artifacts recovered from the site are summarized in Table 1 . The artifacts include 585 flakes, 5 ores, 1 pottery sherd, 1 dart point fragment, and 8 other biface fragments. A total of 12 modified flakes was also recovered. Also collected were 183 pieces of burned rock. Historic material was found only in the upper levels of Test Unit 1 and includes 2 cut nails and 3 fragments of glass. Faunal remains consist of 53 fragments of mussel shell.

Unmodified Flakes (585 specimens)

The distribution of unmodified flakes is summarized in Tables 1 and 2. Almost all of the flakes are of locally available chert. Quartzite was also used. Petrified wood, including occasional pieces of petrified palm wood, was used infrequently. Most of the cortex on the primary and secondary flakes exhibits

water wear, indicating that the lithic material is from a gravel source. The flakes tend to be small; even the hard-hammer flakes. This size differential may reflect limitations placed on the knappers by the use of small gravel as a resource, since the cores found at site 41KA87 tended to be small as well.

Burned Rock (183 specimens)

All the burned rock fragments recovered from the site are very small and average less than $3 \mathrm{gm}$ in weight. The burned rocks tend to be chert, although quartzite is also common. No burned rock clusters were encountered during excavation. 
TABLE 1. Artifact summary.

\begin{tabular}{|c|c|c|c|c|c|c|c|c|c|c|}
\hline \multirow[t]{2}{*}{ Provenience } & \multicolumn{7}{|c|}{ Prehistoric } & \multicolumn{2}{|c|}{ Historic } & \multirow{2}{*}{\begin{tabular}{|l} 
Faunal \\
Mussel \\
Shell
\end{tabular}} \\
\hline & Ceramics & Dart & $\begin{array}{l}\text { Biface } \\
\text { Frag. }\end{array}$ & $\begin{array}{l}\text { Mod. } \\
\text { Flake }\end{array}$ & Core & Flake & $\begin{array}{l}\text { Burned } \\
\text { Rock }\end{array}$ & $\begin{array}{l}\text { Cut } \\
\text { Nail }\end{array}$ & Glass & \\
\hline Surface & -- & 1 & 2 & -- & -- & -- & -- & -- & -- & -- \\
\hline $\begin{array}{cc}\text { Test Unit } & 1 \\
\text { Level } & 1 \\
\text { Level } & 2 \\
\text { Level } & 3 \\
\text { Level } & 4 \\
\text { Level } & 5 \\
\text { Level } & 6 \\
\text { Level } & 7 \\
\text { Level } & 8\end{array}$ & $\begin{array}{l}-- \\
-- \\
-- \\
-- \\
-- \\
-- \\
-- \\
--\end{array}$ & $\begin{array}{l}-- \\
-- \\
-- \\
-- \\
-- \\
-- \\
-- \\
--\end{array}$ & $\begin{array}{r}-- \\
-- \\
-- \\
-- \\
-- \\
1 \\
-- \\
1\end{array}$ & $\begin{array}{l}-- \\
-- \\
-- \\
-- \\
-- \\
1 \\
1 \\
--\end{array}$ & $\begin{array}{l}-- \\
-- \\
-- \\
-- \\
-- \\
-- \\
-- \\
--\end{array}$ & $\begin{array}{r}4 \\
7 \\
21 \\
9 \\
30 \\
18 \\
16 \\
29\end{array}$ & $\begin{array}{r}3 \\
4 \\
\mathbf{3} \\
-- \\
-- \\
12 \\
4 \\
2\end{array}$ & $\begin{array}{l}2 \\
-- \\
-- \\
-- \\
-- \\
-- \\
-- \\
--\end{array}$ & $\begin{array}{l}-- \\
3 \\
-- \\
-- \\
-- \\
-- \\
-- \\
--\end{array}$ & $\begin{array}{r}3 \\
1 \\
1 \\
2 \\
4 \\
-- \\
3 \\
2\end{array}$ \\
\hline $\begin{array}{cc}\text { Test Unit } 2 \\
\text { Level } & 1 \\
\text { Level } & 2 \\
\text { Level } & 3 \\
\text { Level } & 4 \\
\text { Level } & 5\end{array}$ & $\begin{array}{l}-- \\
-- \\
- \\
-- \\
--\end{array}$ & $\begin{array}{l}-- \\
-- \\
-- \\
-- \\
--\end{array}$ & $\begin{array}{r}-- \\
1 \\
-- \\
1 \\
--\end{array}$ & $\begin{array}{r}-- \\
1 \\
1 \\
1 \\
-- \\
--\end{array}$ & $\begin{array}{l}-- \\
-- \\
-- \\
-- \\
-- \\
--\end{array}$ & $\begin{array}{l}42 \\
48 \\
73 \\
41 \\
17\end{array}$ & $\begin{array}{r}3 \\
3 \\
33 \\
7 \\
--\end{array}$ & $\begin{array}{l}-- \\
-- \\
-- \\
-- \\
--\end{array}$ & $\begin{array}{l}-- \\
-- \\
-- \\
-- \\
--\end{array}$ & $\begin{array}{r}3 \\
-- \\
7 \\
2 \\
--\end{array}$ \\
\hline \multirow[t]{2}{*}{$\begin{array}{cc}\text { Test Unit } & 3 \\
\text { Level } & 1 \\
\text { Level } & 2 \\
\text { Level } & 3 \\
\text { Level } & 4 \\
\text { Level } & 5\end{array}$} & $\begin{array}{r}-- \\
-- \\
1 \\
-- \\
--\end{array}$ & $\begin{array}{l}-- \\
-- \\
-- \\
-- \\
--\end{array}$ & $\begin{array}{r}-- \\
-- \\
1 \\
1 \\
--\end{array}$ & $\begin{array}{r}-- \\
2 \\
3 \\
2 \\
--\end{array}$ & $\begin{array}{r}3 \\
-- \\
2 \\
-- \\
--\end{array}$ & $\begin{array}{r}49 \\
51 \\
76 \\
48 \\
6\end{array}$ & $\begin{array}{r}21 \\
34 \\
24 \\
28 \\
2\end{array}$ & $\begin{array}{l}-- \\
-- \\
-- \\
-- \\
--\end{array}$ & $\begin{array}{l}-- \\
-- \\
-- \\
-- \\
--\end{array}$ & $\begin{array}{l}6 \\
6 \\
1 \\
7 \\
5\end{array}$ \\
\hline & 1 & 1 & 8 & 12 & 5 & 585 & 183 & 2 & 3 & 53 \\
\hline
\end{tabular}


TABLE 2. Distribution of flakes by decortication type.

\begin{tabular}{|c|c|c|c|c|}
\hline Provenience & Primary & Secondary & Interior & Shatter \\
\hline $\begin{array}{cc}\text { Test Unit } & 1 \\
\text { Level } & \mathbf{1} \\
\text { Level } & \mathbf{2} \\
\text { Level } & \mathbf{3} \\
\text { Level } & 4 \\
\text { Level } & 5 \\
\text { Level } & 6 \\
\text { Level } & 7 \\
\text { Level } & 8\end{array}$ & $\begin{array}{c}2 \\
-- \\
1 \\
1 \\
1 \\
1 \\
1 \\
1\end{array}$ & $\begin{array}{r}-- \\
4 \\
7 \\
2 \\
9 \\
6 \\
8 \\
9\end{array}$ & $\begin{array}{r}1 \\
2 \\
11 \\
4 \\
20 \\
11 \\
6 \\
17\end{array}$ & $\begin{array}{r}1 \\
1 \\
2 \\
2 \\
-- \\
-- \\
1 \\
2\end{array}$ \\
\hline $\begin{array}{c}\text { Test Unit } \mathbf{2} \\
\text { Level } \mathbf{1} \\
\text { Level } \mathbf{2} \\
\text { Level } \mathbf{3} \\
\text { Level } 4 \\
\text { Level } 5\end{array}$ & $\begin{array}{r}1 \\
2 \\
2 \\
1 \\
--\end{array}$ & $\begin{array}{r}11 \\
15 \\
17 \\
9 \\
2\end{array}$ & $\begin{array}{l}27 \\
30 \\
46 \\
30 \\
14\end{array}$ & $\begin{array}{l}3 \\
1 \\
8 \\
1 \\
1\end{array}$ \\
\hline 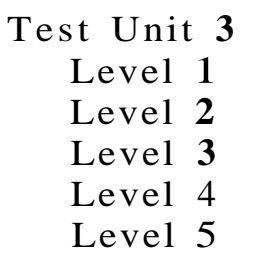 & $\begin{array}{r}2 \\
2 \\
6 \\
2 \\
--\end{array}$ & $\begin{array}{r}17 \\
24 \\
44 \\
24 \\
2\end{array}$ & $\begin{array}{r}20 \\
23 \\
26 \\
22 \\
3\end{array}$ & $\begin{array}{r}10 \\
2 \\
-- \\
-- \\
1\end{array}$ \\
\hline Totals & 26 & 210 & 313 & 36 \\
\hline
\end{tabular}


Prehistoric Pottery (1 specimen, Figure 4A)

This specimen is a plain body sherd with a small amount of bone temper and is about $9 \mathrm{~mm}$ thick. The paste is slightly sandy in texture, and it is dark brown in color. The sherd is soft and has not been well fired. It is too fragmentary to determine the type of vessel it represents. The presence of pottery indicates a Late Prehistoric component at the site.

Dart Point Fragment (1 specimen, Figure 4B)

The dart point fragment was found on the surface and its horizontal provenience is unknown. The fragment includes the stem and proximal portion of the blade. The stem is parallel-sided with a slightly convex base. Shoulders are present and are distinct, but rounded. This specimen bears similarities to the Morhiss type, and probably dates from the Late Archaic.

Biface Fragments ( 8 specimens, Figure $4 \mathrm{C}-\mathrm{F}$ )

Almost all of the bifaces were found in the middle and lower levels of the site. The significance of this distribution should not be overemphasized due to the small sample size involved, but may indicate different sets of activities during different occupations at the site (i.e., upper vs. middle/lower levels). Most of the bifaces exhibit relatively little thinning and their outlines have only been minimally shaped. Therefore, most of the bifaces represent tool blanks which were abandoned during manufacture. 


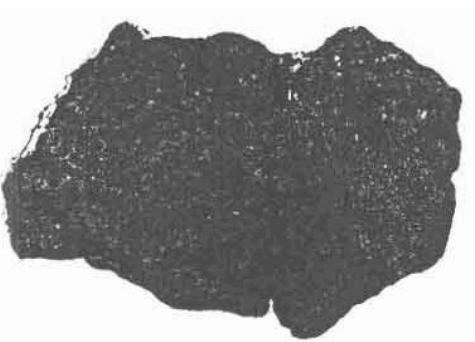

A

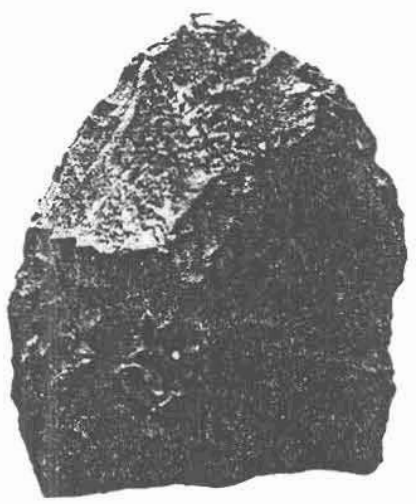

D

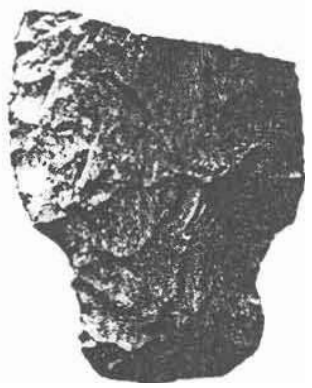

B

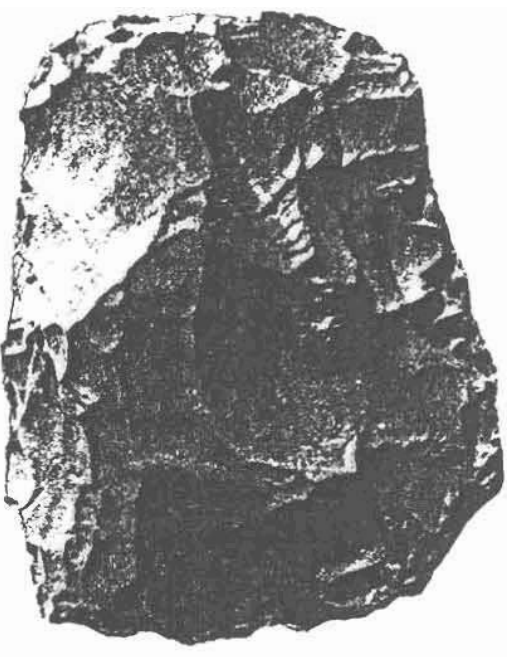

C

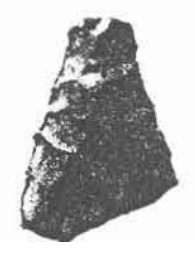

E

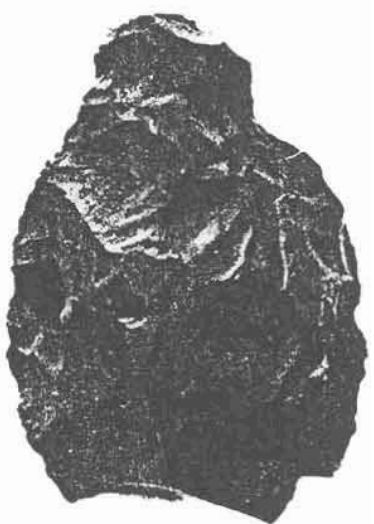

$\mathrm{F}$

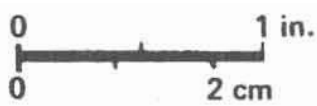

FIGURE 4. Artifacts from Site 41KA87. A, prehistoric pottery sherd; $\mathrm{B}$, dart point fragment; $\mathrm{C}-\mathrm{F}$, biface fragments. 
Modified Flakes (12 specimens)

The modified flakes all represent make-shift cutting tools and follow a vertical distribution similar to the bifaces described above. They have been modified through use rather than through purposeful chipping. None of the specimens exhibit resharpening or deliberate shaping of the working edge. The use wear visible on the flakes tends to be very light indicating that the flakes were used once and then discarded and that cutting was of a relatively soft material such as meat or softened hide.

Cores (5 specimens, Figure 5A,B)

The cores are all multidirectionally flaked. All are small and exhausted (or nearly so) in terms of producing workable flakes. Those which exhibit cortex appear to be from a gravel source rather than directly from an outcrop.

Historic Material (5 specimens, Figure 5C-E)

A total of 2 cut nails and 3 fragments of glass was found in the upper two levels of Test Unit 1. The glass includes 2 pieces of flat, clear glass which have been subjected to heating and are partially melted. Whether these glass sherds are parts of a window or a glass vessel could not be determined.

The third fragment of glass is from the lip of a small bottle. The glass is clear with a slightly bluish tint. A mold seam is visible on the side of the fragment along the neck, but the seam ends abruptly at the bottom of the lip. The lip appears to have been applied to the neck after the bottle came out of the mold. This technique was common in glass bottle manufacture between 


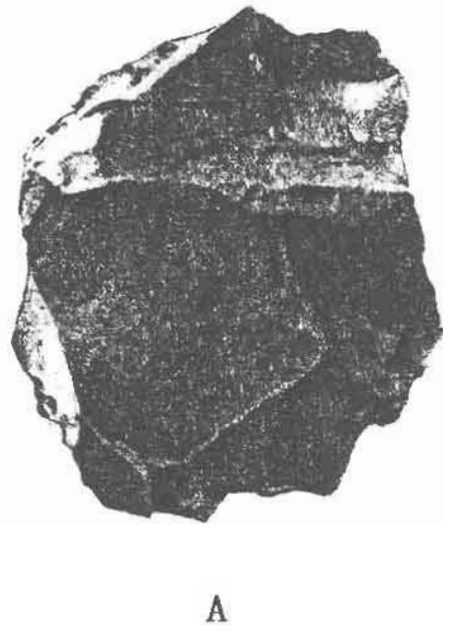

A

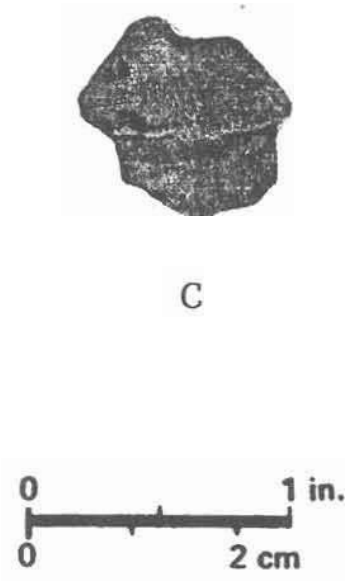

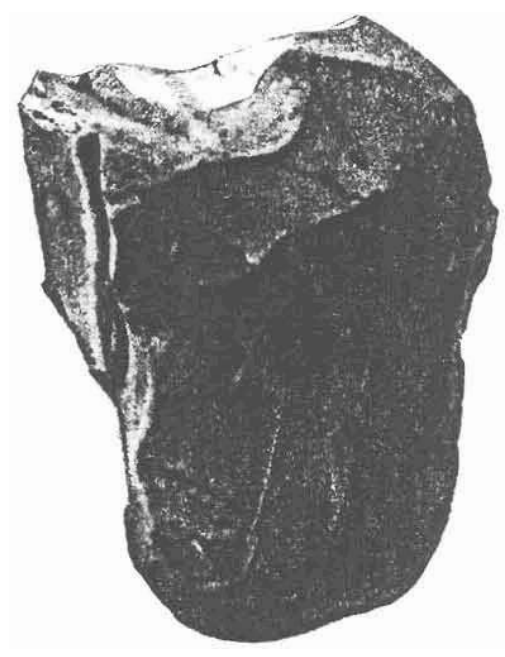

B
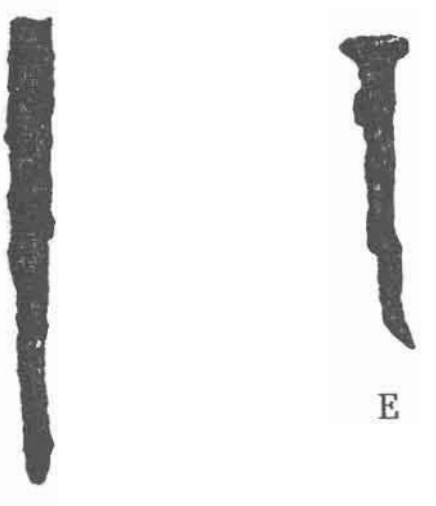

E

FIGURE 5. Artifacts from Site 41KA87. A,B, cores; C-E, glass bottle lip and cut nails. 
ca. 1870 and ca. 1906. This time period fits with the cut nails which occurred in Level 1. All 3 glass fragments have been chemically etched by the surrounding soil.

Mussel Shell Fragments (53 specimens)

The only faunal remains recovered were mussel shells. All of the specimens appear to be from small individuals. Of those that can be identified, the genus Amblema is dominant.

Smooth Stone (3 specimens)

In addition to the artifacts described above, 3 smooth stones were recovered during testing. They are spheroidal in shape and at least one of them is a fossil sea urchin. None of them appears to have been battered. Although they may be purposefully smoothed, they are natural river pebbles. 
CONCLUSIONS

Site 41KA87 is a multicomponent prehistoric campsite occupied during the Late Archaic and Late Prehistoric periods. All of the occupations appear to have been ephemeral since the tool kit represented at the site is dominated by make-shift tools, there were few finished implements, and no features were found. Much of the site has been disturbed by earlier highway construction and maintenance and the deposits are shallow.

Although the site is now on a hill overlooking the San Antonio River, the river has been extremely active and is currently cutting toward the site. Since the river has not always been adjacent to the site, it should not be assumed that the site was focussed toward riverine resources throughout time. Even so, the faunal remains consist predominantly of mussel shell which can be obtained from the river or any of its tributaries. Therefore a riverine orientation seems to have been dominant during some of the occupations at the site.

Because of the shallow and disturbed nature of the deposits, the relatively low artifact yield, lack of features, and ephemeral nature of the occupations, the site is not considered to be eligible for nomination to the National Register of Historic Places (under $36 \mathrm{CFR}$, Part 800). The site is likewise not recommended for State Archeological Landmark designation. No further archaeological investigation is considered necessary, 


\section{REFERENCES CITED}

Andrews, Susan L.

1981 Archaeological Survey and Assessment along Segments of Overhead Power Line Rights-of-way in Atascosa, Karnes, and McMullen Counties, Texas. Prewitt and Associates, Inc., Report of Investigations No. 6. Austin.

Bandy, Philip A.

1981 Part II: Historical Archaeological Resources of the Choke Canyon Reservoir Area in McMullen and Live Oak Counties, Texas. Center for Archaeological Research, The University of Texas at San Antonio, Choke Canyon Series, Vol. 2:67-190. San Antonio.

Birmingham, W. W.

1980 Scottsbluff Points from Victoria and DeWitt Counties. La Tierra 7(4) :27-29.

Blair, W. Frank

1950 The Biotic Provinces of Texas. Texas Journal of Science, $1(2): 93-116$.

Brown, Kenneth M., Daniel R. Potter, Grant D. Hall, and Stephen L. Black 1982 Excavations at 41LK67, A Prehistoric Site in the Choke Canyon Reservoir. Center for Archaeological Research, The University of Texas at San Antonio, Choke Canyon Series, Vol. 7. San Antonio.

Calhoun, Cecil A.

1979 A Small Campsite near Kenedy, Texas. La Tierra 6(3):12-15. San Antonio.

Campbell, T.N. and T.J. Campbell

1981 Historic Indian Groups of the Choke Canyon and Surrounding Area, Southern Texas. Center for Archaeological Research, The University of Texas at San Antonio, Choke Canyon Series, Vol. 1. San Antonio.

Carr, John T., Jr.

1977 The Climate and Physiography of Texas. Texas Water Development Board, Report 38. Austin.

Clark, John W., Jr.

1985 Historical and Archaeological Resources of Riverdale, a Company Town in Goliad County, Texas. State Department of Highways and Public Transportation Publications in Archaeology No. 29. 
Cole, Nancy Mottashed

1981 Archeological and Historical Survey of the Proposed Critical Area Treatment Measures on the Frank Dragon Property and the Joe Dragon Property, Ecleto Creek Watershed, Karnes County, Texas. Soil Conservation Service. Temple.

Cox, Wayne

1978 An Archaeological Assessment of the Stockdale City Park, Stockdale, Texas. Center for Archaeological Research, The University of Texas at San Antonio. Letter report on file at TARL, Austin.

Crawford, Daymond D.

1971 An Archeological Reconnaissance of Ecleto Creek Watershed, South Central Texas. Texas Archeological Salvage Project, Survey Reports No. 8. Austin.

Denton, Joe T.

1984 Research Design for Testing Archaeological Site 41KA25, Karnes County, FM 81: At Cibolo Creek. Manuscript on file at the Texas State Department of Highways and Public Transportation. Austin.

Dibble, David S.

1979 Archeological Assessments at the Three Rivers Flood Protection Project, Live Oak County, Texas. Texas Archeological Survey, The University of Texas at Austin, Technical Bulletin 26. Austin.

Everett, Diana

1981 Part I: Historical Resources of the Choke Canyon Reservoir in McMullen and Live Oak Counties, Texas. Center for Archaeological Research, The University of Texas at San Antonio, Choke Canyon Series, Vol. 2:1-64. San Antonio.

Fox, Anne A.

1986 Archaeological Investigations at Historic Sites in the Choke Canyon Reservoir, Southern Texas. Center for Archaeological Research, The University of Texas at San Antonio, Choke Canyon Series, Vol. 12. San Antonio.

1984 A Study of Five Historic Cemeteries at Choke Canyon Reservoir, Live Oak and McMullen Counties, Texas. Center for Archaeological Research, The University of Texas at San Antonio, Choke Canyon Series, Vol. 9. San Antonio.

Fox, Anne A., Stephen L. Black and Steven R. James

1979 Intensive Survey and Testing of Archaeological Sites on Coleto Creek, Victoria and Goliad Counties, Texas. Center for Archaeological Research, The University of Texas at San Antonio Report No. 67. 
Fox, Anne A. and Thomas R. Hester

1976 An Archaeological Survey of Coleto Creek, Victoria and Goliad County, Texas. Center for Archaeological Research, The University of Texas at San Antonio Archaeological Survey Report No. 18.

Fox, Daniel E.

1979 Archaeological Investigation of Five Prehistoric Sites on the Coleto Creek Drainage, Goliad County, Texas. Center for Archaeological Research, The University of Texas at San Antonio Report №. 69 .

Gilmore, Kathleen

1974 Mission Rosario. Texas Parks and Wildlife Department Archeological Report No. 14, Part I; Austin.

1975 Mission Rosario, Archeological Investigation. Texas Parks and Wildlife Department Archeological Report No. 14, Part II.

Goode, Glenn T.

n.d. Manuscript in preparation describing test excavations at 41KA25 and 41KA85, and surface inspection of 41KA26. On file at the Texas Department of Highways and Public Transportation. Austin.

Hall, Grant D., Stephen L. Black, and Carol Graves

1982 Archaeological Investigations at Choke Canyon Reservoir. Center for Archaeological Research, The University of Texas at San Antonio, Choke Canyon Series, Vol. 5. San Antonio.

Hall, Grant D., Thomas R. Hester, and Stephen L. Black

1986 The Prehistoric Sites at Choke Canyon Reservoir, Southern Texas: Results of Phase II Archaeological Investigations. Center for Archaeological Research, The University of Texas at San Antonio, Choke Canyon Series, Vol. 10. San Antonio.

Hester, Thomas R.

1968 Paleo-Indian Artifacts from the sites along San Miguel Creek: Frio, Atascosa, and McMullen Counties, Texas. Texas Archeological Society, Bulletin. 39:147-162.

Highley, Cheryl Lynn

1986 Archaeological Investigations at 41LK201, Choke Canyon Reservoir, Southern Texas. Center for Archaeological Research, The University of Texas at San Antonio, Choke Canyon Series, Vol. 11. San Antonio.

Hsu, Dick Ping and Ronald W. Ralph

1968 An Appraisal of the Archeological Resources of Cibolo Reservoir, Wilson County, Texas. Texas State Building Commission and Texas State Water Development Board, Archeological Survey Report No. 1. Austin. 
Ivey, James E.

1983 Archaeological Testing at Rancho de las Cabras, 41WN30, Wilson County, Texas: Second Season. Center for Archaeological Research, The University of Texas at San Antonio Archaeological Survey Report No. 121. San Antonio.

Ivey, James E. and Anne A. Fox

1981 Archaeological Survey and Testing at Rancho de las Cabras, Wilson County, Texas. Center for Archaeological Research, The University of Texas at San Antonio, Archaeological Survey Report No. 104. San Antonio.

Johnson, Charles E., III

1977 Initial Testing Report, Site 41LK28. Unpublished testing report on file at the Texas State Department of Highways and Public Transportation. Austin, Texas.

Johnson, LeRoy, Jr.

1986 A Plague of Phases. Texas Archeological Society, Bulletin 57:1-26.

Jones, Courtenay J. and Anne A. Fox

1983 Archaeological Testing at Rancho de las Cabras, Wilson County, Texas. Center for Archaeological Research, The University of Texas at San Antonio, Archaeological Survey Report No. 123. San Antonio.

Jurgens, Christopher James

1980 Food and the Environment - A Model of Potential Resource Variation for portions of the Choke Canyon Reservoir Area of South Texas.

M.A. Thesis, Texas Tech University, Lubbock.

Kotter, Steven M. and Jan A. Guy

1980 Archeological Survey and Assessment of Two Areas to be Affected by Proposed Critical Area Treatment Measures in the Ecleto Creek Watershed, Karnes County, Texas. Prewitt and Associates, Inc., Report of Investigations No. 5. Austin.

Labadie, Joseph $\mathrm{H}$.

1985 A Reevaluation of Four Prehistoric Sites (41LK203,41LK204, 41LK205, and 41LK206)Near the Choke Canyon Reservoir in Live Oak County, Texas. Center for Archaeological Research, The University of Texas at San Antonio, Archaeological Survey Report No. 149. San Antonio.

Larkin, Thomas J., and George W. Bomar

1983 Climatic Atlas of Texas. Texas Department of Water Resources, Report LP-192. Austin.

Laurens, Jan C., Jan A. Guy, and Elton R. Prewitt

1979 Archeological Assessment at Two Sites in the Proposed Path City Park, Wilson County, Texas. Reports of Investigations, No. 2. Prewitt and Associates, Inc. 
Lynn, Warren M., Daniel E. Fox, and Nancy O'Malley

1977 Cultural Resource Survey of Choke Canyon Reservoir, Live Oak and McMullen Counties. Texas Historical Commission, Archeological Survey Report No. 20. Austin.

Mallouf, Michael G.

1975 Three Rivers Flood Protection Project, Live Oak County, Texas: An Archeological Survey of Areas Proposed for Modification. Texas Archeological Survey, The University of Texas at Austin, Technical Bulletin 9. Austin.

1977 Additional Archeological Survey in Areas to be Affected by the Three Rivers Flood Protection Project, Live Oak County, Texas. Texas Archeological Survey, The University of Texas at Austin, Technical Bulletin 16. Austin.

McGraw, A. Joachim

1979 An Archaeological and Historical Survey of the Haase, Moy, and Wiatrek Properties of the Conquista Project. Center for Archaeological Research, The University of Texas at San Antonio, Archaeological Survey Report No. 81. San Antonio.

McReynolds, Richard

1987 Additional Paleo-Indian Artifacts from the Coleto Creek Project Area of Southern Texas. La Tierra 8(3):28-31.

McReynolds, Richard, Ben McReynolds, and Mike McReynolds

1979 Additional Paleo-Indian Artifacts from San Miguel Creek, Atascosa County, Texas. La Tierra 6(2):20-25..

1980 Additional Late Paleo-Indian Artifacts from Southwestern Atascosa County, Texas. La Tierra 7(3) :34-38.

Mounger, Maria Allen

1959 Mission Espiritu Santo of Coastal Texas: An Example of Historic Site Archeology. MA Thesis. The University of Texas at Austin.

Nightengale, Bruce A. and Leland C. Bement

1982 A Cultural Resource Survey and Assessment of the Texaco-Sunedco Hobson Uranium Prospect, Karnes County, Texas. Texas Archeological Survey, The University of Texas at Austin, Technical Bulletin 51. Austin.

Patterson, Patience E.

1987 Test Excavations Along Interstate 37 at Oakville, Live Oak County, Texas. Texas State Department of Highways and Public Transportation, Publications in Archaeology, Report No. $35 . \quad$ Austin. 
Pliska, James R.

1980 Archeological Investigations at the Three Rivers Flood Control Project: A Final Report. Texas Archeological Survey, The University of Texas at Austin, Technical Bulletin 30. Austin.

Prewitt, Elton R.

1981 Cultural Chronology in Central Texas. Texas Archeological Society, Bulletin 52:65-90.

Prewitt, Elton R. and Robert F. Scott IV

1977 Three Rivers Floodwater Diversion Levee Project Assessments at Archaeological Sites 41LK57, 41LK133, and 41LK144. Texas Archeological Survey, Technical Bulletin 18.

Reed, Erik K.

1983 Burials at Mission Espiritu Santo. Central Texas Archeologist, No. $4: 85-95$.

Roemer, Erwin

1980 An Archaeological Survey for the Conquista Project of Niewschwietz-Bodden Properties, Karnes County, Texas. Center for Archaeological Research, The University of Texas at San Antonio, ArchaeologicalSurvey Report No 92. San Antonio.

1981 The 1979 Archeological Survey of Portions of the Choke Canyon Reservoir in LiveOak and McMullen Counties, Texas. Center for Archaeological Research, The University of Texas at San Antonio, Choke Canyon Series, Vol. 4.

Scott, Robert F. IV, and Daniel E. Fox

1982 Excavations at Sites 41LK31, 41LK32, and 41LK202 in the Choke Canyon Reservoir, South Texas. Center for Archaeological Research, The University of Texas at San Antonio, Choke Canyon Series, Vol. 8.

Taylor, Anna J. and Anne A. Fox

1985 Archeological Survey and Testing at Rancho de las Cabras, Wilson County, Texas: Fifth Season. Center for Archaeological Research, The University of Texas at San Antonio, Archaeological Survey Report No. 144 .

Thoms, Alston V., John L. Montgomery and Alice W. Portnoy

1981 An Archaeological Survey of a Portion of the Choke Canyon Reservoir Area in McMullen and Live Oak Counties, Texas. Center for Archaeological Research, The University of Texas at San Antonio, Choke Canyon Series, Vol. 3.

Wakefield, Walter N.

1968 Archeological Surveys of Palmetto Bend and Choke Canyon Reservoirs, Texas. Texas Archaeological Salvage Project, Report No. 5. 
Weed, Carol S. and Harry J. Shafer

1981 Archaeological Testing and Collecting at Choke Canyon Reservoir, Nueces River Project, Texas. Center for Archaeological Research, The University of Texas at San Antonio, Choke Canyon Series, Vol. 6.

Weir, Frank A.

1976 The Central Texas Archaic. Unpublished Ph.D. dissertation, Washington State University, Pullman, Washington. 